\title{
The Evolution of the E-Vehicle Industry and its Path Towards Setting up Dominance in Automobile Industry - A Case Study
}

\author{
Anantha Murthy ${ }^{1,2}$ \& Nethravathi P. S. ${ }^{3}$ \\ ${ }^{1}$ Research Scholar, College of Computer Science and Information Science, Srinivas \\ University, Mangaluru, India \\ ${ }^{2}$ Assistant Professor, Dept of M.C.A, NMAMIT, Nitte, Karkala, India \\ OrcidID: 0000-0002-9009-7541; E-mail: anantham2004@ gmail.com \\ ${ }^{3}$ Professor, College of Computer Science and Information Science, Srinivas University, \\ Mangaluru, India \\ OrcidID: 0000-0001-5447-8673; E-mail: nethrakumar590@gmail.com
}

Area of the Paper: Technology Management.

Type of the Paper: Research Case Study.

Type of Review: Peer Reviewed as per $|\mathrm{C}| \mathrm{O}|\mathrm{P}| \mathrm{E} \mid$ guidance.

Indexed In: OpenAIRE.

DOI: https://doi.org/10.5281/zenodo.5149607

Google Scholar Citation: IJCSBE

\section{How to Cite this Paper:}

Anantha Murthy \& Nethravathi, P. S., (2021). The Evolution of the E-Vehicle Industry and its Path Towards Setting up Dominance in Automobile Industry - A Case Study. International Journal of Case Studies in Business, IT, and Education (IJCSBE), 5(2), 3849. DOI: https://doi.org/10.5281/zenodo.5149607

International Journal of Case Studies in Business, IT and Education (IJCSBE)

A Refereed International Journal of Srinivas University, India.

Crossref DOI : $\underline{\text { https://doi.org/10.47992/IJCSBE.2581.6942.0118 }}$

(C) With Authors.

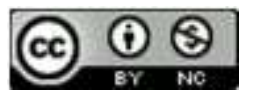

This work is licensed under a Creative Commons Attribution Non-Commercial 4.0 International License subject to proper citation to the publication source of the work.

Disclaimer: The scholarly papers as reviewed and published by the Srinivas Publications (S.P.), India are the views and opinions of their respective authors and are not the views or opinions of the S.P. The S.P. disclaims of any harm or loss caused due to the published content to any party. 


\title{
The Evolution of the E-Vehicle Industry and its Path Towards Setting up Dominance in Automobile Industry - A Case Study
}

\author{
Anantha Murthy ${ }^{1,2}$ \& Nethravathi P. S. ${ }^{3}$ \\ ${ }^{1}$ Research Scholar, College of Computer Science and Information Science, Srinivas \\ University, Mangaluru, India \\ ${ }^{2}$ Assistant Professor, Dept of M.C.A, NMAMIT, Nitte, Karkala, India \\ OrcidID: 0000-0002-9009-7541; E-mail: anantham2004@ gmail.com \\ ${ }^{3}$ Professor, College of Computer Science and Information Science, Srinivas University, \\ Mangaluru, India \\ OrcidID: 0000-0001-5447-8673; E-mail: nethrakumar590@gmail.com
}

\begin{abstract}
Background/Purpose: The electric vehicle (EV) has gained a lot of attention from researchers in the twenty-first century as a green travel tool, leading to a series of in-depth studies. With the advancement of high-capacity batteries and electric vehicles, the value of electric vehicles will skyrocket, posing new problems to the power grid's safe and stable operation. This article briefly discusses a certain area of electric vehicles, such as government legislation, employability options, market trends, problems, and solutions to connected issues.

Objective: The growth of the vehicle industry and its progress toward the government of India's "Make in India" mission for electric vehicles, as part of the National Electric Mobility Mission Plan to set up dominance in the automobile industry.

Design/Methodology/Approach: Presentation of information collected from various scholarly articles, web articles, and analysis using the SWOC framework.

Findings/Results: Based on the analysis of facts and figures and also by looking at the various scenarios of expansion of the electric vehicle industry in India, it is seen that this industry has seen considerable growth and progress in various avenues such as creating employment opportunities and country's economy. Few recommendations are also suggested to take the concept further.
\end{abstract}

Research limitations/implications: The study is limited to the electric vehicle industry, though a total of 25 Industry sectors have been identified under 'Make in India'.

Originality/Value: This paper focuses on the growth of the electric vehicle industry and the factors that helped towards making 'Make in India' a reality. It also talks about the support given by Government to achieve the same.

Paper Type: A Research Case study paper on the growth and dominance of the electric vehicle Industry and realization of the 'Make in India' concept.

Keywords: Industry analysis, Automobile industry, EVs; Conventional HEVs (Hybrid Electric cars); PHEVs; Electric vehicles, BEVs, Electric fleet.

\section{INTRODUCTION :}

An industry is a system made up of a collection of manufacturers or firms with the common goal of producing a specific type of product or service. Industry analysis is a sort of case method research that is used to investigate a specific industry or industry area to generate new knowledge about it [1]. In this paper, we chose the electric vehicle industry.

Electric vehicles (EVs) first appeared in the mid-19th century, when electricity was one of the most common methods of motor vehicle propulsion, and they offered a level of comfort and convenience that gasoline-powered cars couldn't match. The term "electric vehicle" refers to a vehicle that runs on electricity (EV). As a result of technology developments, a greater focus on renewable energy, and the 
chance to reduce transportation's influence on climate change and other environmental concerns, EVs have made a comeback in the twenty-first century [2].

The electric vehicle construction is a difficult sector to master since it incorporates several factors such as interior space, dynamic performance, functional safety and performance, communication, and so on. A hybrid electric car's gasoline engine is comparable to that of a traditional indoor fire engine. The engine, on the other hand, is compact and employs new technology, which can minimize emissions and increase efficiency. A hybrid electric vehicle's transmission serves the same purpose as a conventional vehicle's transmission.

Overall, the global electric vehicle (EV) market is expected to grow in the future due to the rapidly increasing year-over-year adoption rate of electric vehicles around the world, as well as favorable policies, incentives, and subsidies implemented by several state governments, and the rapid development of EV-supporting infrastructure.

\section{RELATED PUBLICATION WORK :}

Sharmila, B. et al. (2021) in their paper discussed the drawbacks of fuel-based vehicles. Their study focuses on the development of an electric vehicle model that is high-performance, low-maintenance, and energy-efficient [3]. S. Goel et al. (2021) paper's key novelty is that it presents a summary of electric vehicle hurdles and issues in the Indian setting [4]. The information presented by P. Goel et al. (2021) shows that EV pricing is not a major concern and does not deter people from purchasing them, which is surprising and contradictory to previous research. In fact, after acquiring an EV, customers are more concerned about upkeep [5]. S. Saxena et al. (2014) in their study discussed the consumption of electricity for two, three, and four-wheelers for the Indian context considering the different areas like battery model, chassis model, wheel model, motor model, etc [6]. The data analysis section of the study by Sharma, S. et al. (2021) aids in understanding the current situation of electric vehicle policy implementation in various states [7]. The study by Mirwani, P. M et al. (2021) intends to examine Indian automobile production and sales trends on the one hand, as well as the challenges and opportunities encountered by the Indian electric vehicle market [8].

Some of the scholarly papers published for the EV industry are tabulated with the area of study, issues discussed, and the author's details.

Table 1: Publication by various scholars on EVehicle issue:

\begin{tabular}{|l|l|l|l|}
\hline $\begin{array}{l}\text { Sl. } \\
\text { No }\end{array}$ & Area & Issues & Authors \\
\hline 1 & E. Vehicle & $\begin{array}{l}\text { The report gives an outline of present and } \\
\text { future trends in the EV industry. The } \\
\text { effects of rapid electric motor } \\
\text { development, power natural philosophy, } \\
\text { electronics, and newer materials. }\end{array}$ & Chan, C. (1993). [9] \\
\hline 2 & Strategy & $\begin{array}{l}\text { This paper deals with the strategy used } \\
\text { for charging optimization based on the } \\
\text { cost of electricity and response to } \\
\text { demand. }\end{array}$ & \\
\hline 3 & Service & $\begin{array}{l}\text { This article examines the charging } \\
\text { facility's operational platform from a a). [10] } \\
\text { variety of angles, including the user's } \\
\text { mobile terminal, consumption capacity, } \\
\text { and payment patterns. }\end{array}$ & Liu et al. (2020). [11] \\
\hline 4 & Infrastructure & $\begin{array}{l}\text { This article focuses on the prediction of } \\
\text { electric car sales in European countries, } \\
\text { as well as the conditions and assumptions } \\
\text { that were utilized to make that estimate. }\end{array}$ & Vražić, M. et al. (2014). [12] \\
\hline 5 & Process & $\begin{array}{l}\text { In this study, regenerative braking in } \\
\text { electric vehicles is discussed. The } \\
\text { conditions for regeneration, the flow of }\end{array}$ & Totev, V. et al. (2020). [13] \\
\hline
\end{tabular}




\begin{tabular}{|l|l|l|l|}
\hline & & $\begin{array}{l}\text { energy during the process, and the } \\
\text { strategies for execution are all explored. }\end{array}$ & \\
\hline 6 & Strategy & $\begin{array}{l}\text { The goal of this study is to offer a } \\
\text { solution for properly allocating EVCS in } \\
\text { a distribution environment. }\end{array}$ & $\begin{array}{l}\text { Archana, A. N, et al. (2020). } \\
{[14]}\end{array}$ \\
\hline 7 & Marketing & $\begin{array}{l}\text { In the electric car market in India, electric } \\
\text { vehicle supply equipment and worldwide } \\
\text { available chargers (both AC and DC) are } \\
\text { discussed in this article. Based on recent } \\
\text { laws imposed by the Government of } \\
\text { India, an economic model for installing } \\
\text { EV charging infrastructure at a mall in } \\
\text { India is provided. }\end{array}$ & Das, (2019). [15] \\
\hline 8 & Service & $\begin{array}{l}\text { This study proposes a hierarchical control } \\
\text { at the utility level to achieve peak cutting } \\
\text { with EVs. }\end{array}$ & Shereef, R. M. (2020). [16] \\
\hline 9 & Infrastructure & $\begin{array}{l}\text { This analysis, which is the first of its type } \\
\text { for India, can help to speed EV adoption, } \\
\text { open up innovation opportunities for both } \\
\text { the transportation and electric industries, } \\
\text { and assist energy security, and enhanced } \\
\text { urban air quality goals. }\end{array}$ & Ghatikar, G. et al. (2016). [17] \\
\hline 10 & Process & $\begin{array}{l}\text { This study is about finding ideal locations } \\
\text { in India to set up and installing charging } \\
\text { stations }\end{array}$ & Sasidharan, C. et al. (2019). \\
S18]
\end{tabular}

\section{OBJECTIVES :}

The papers described in the related research section deal with government initiatives, market trends, and the growth of the electric vehicle industry. A few of the following objectives are developed by analyzing those papers.

(1) To learn about India's government incentives for plug-in electric vehicles in India. Central and state governments are encouraging companies to sell electric vehicles and citizens to purchase electric vehicles.

(2) To study the employability options in the electric vehicle industry in India. This objective is considered because this is the area where all kinds of employability skills are required.

(3) To study the top companies and competitors in the EV industry in India. India is coming up with many electric vehicles. Many companies are stepping forward in designing electric vehicles with new ideas and strategies to compete with their competitors.

(4) To know the growing status of electric vehicles sales in India. Indian electric vehicle industry got its space in the automobile industry market.

(5) To know about the CSR activities of the electric vehicle industry.

(6) To know about the COVID-19'S Effect on the electric vehicle industry.

(7) SWOC analysis of EV industry in India.

\section{METHODOLOGY :}

The information required for this case study is collected through various secondary sources such as journals, published papers, archived newspaper articles, and websites of the Government of India's electric vehicle Industry.

\section{INCENTIVES FOR PLUG-IN ELECTRIC VEHICLES FROM THE GOVT :}

In India, govt. incentives for plug-in electric vehicles have been established to boost policy-driven adoption. In India, electric vehicles are still more expensive than in many wealthy countries. To 
encourage the production and use of electric vehicles, the state and central governments have announced many schemes and subsidies. The central government's FAME-II scheme gives offers to up to $40 \%$ of vehicle cost for two-wheelers and up to 1.5lacs for four-wheelers. The Goods and Services Tax (GST) is now levied at a lower rate of 5\% on all-electric vehicles [19]. Following the launch of the FAME India scheme, which aims to transition towards e-mobility in the light of expanding international policy commitments and environmental difficulties, the EV market in India has gained substantial traction [20]. The five Indian states with the largest electric vehicle incentives are mentioned below.

Table 2: Top 5 Indian states with largest incentives.

\begin{tabular}{|l|l|l|l|}
\hline $\begin{array}{l}\text { Sl. } \\
\text { No }\end{array}$ & State & \multicolumn{1}{|c|}{ Subsidy for } \\
\hline 1 & Delhi & $\begin{array}{l}\text { Two-wheelers } \\
\text { Up to Rs. 30000, Road tax and } \\
\text { registration exception }\end{array}$ & $\begin{array}{l}\text { Up to Rs. 1.5lakh, Road tax, and } \\
\text { registration exception }\end{array}$ \\
\hline 2 & Gujarat & $\begin{array}{l}\text { Up to Rs. 20000, Road tax and } \\
\text { registration exception }\end{array}$ & $\begin{array}{l}\text { Up to Rs. 1.5lakh, Road tax, and } \\
\text { registration exception }\end{array}$ \\
\hline 3 & Maharashtra & $\begin{array}{l}\text { Rs. 5000, Road tax and } \\
\text { registration exception }\end{array}$ & $\begin{array}{l}\text { Rs. 1lakh, Road tax, and } \\
\text { registration exception }\end{array}$ \\
\hline 4 & Meghalaya & $\begin{array}{l}\text { Rs.10000 per kWh of battery } \\
\text { capacity, Road tax, and } \\
\text { registration exception }\end{array}$ & $\begin{array}{l}\text { Rs. 4000 per kWh of battery } \\
\text { capacity, Road tax, and } \\
\text { registration exception }\end{array}$ \\
\hline 5 & $\begin{array}{l}\text { Karnataka, Andhra } \\
\text { Pradesh }\end{array}$ & Road tax and registration exception \\
\hline
\end{tabular}

\section{EMPLOYABILITY OPTIONS IN THE ELECTRIC VEHICLE INDUSTRY IN INDIA :}

The EV industry is estimated to provide over 5 crore direct and indirect job possibilities, according to the Ministry of Skill Development and Entrepreneurship. India is expected to switch about $25 \%$ of the transportation to electric vehicles by 2030. The Indian labor Organization report stated that the Renewable Energy industry's job opportunities would raise to 38lacs by 2030 [21]. The following table shows the job opportunities in the EV industry.

Table 3: Job Opportunities in the electric vehicle industry.

\begin{tabular}{|c|c|c|c|}
\hline $\begin{array}{l}\text { Sl. } \\
\text { No }\end{array}$ & Area & Challenges & Qualification \\
\hline 1 & $\begin{array}{l}\text { Research and } \\
\text { Development }\end{array}$ & $\begin{array}{l}>\text { Battery Type } \\
>\text { Battery Design } \\
>\text { Battery Management System } \\
\text { Improvement } \\
>\text { Recharging Technology }\end{array}$ & $\begin{array}{llr}\text { Masters or } & \text { Bachelors } \\
\text { engineer in } & \text { Chemical, } \\
\text { Electronics } & \& & \text { Electrical } \\
\text { sector } & & \end{array}$ \\
\hline 2 & $\begin{array}{l}\text { Design and } \\
\text { Development }\end{array}$ & $\begin{array}{l}>\text { Battery Design } \\
>\text { Electronic Circuits } \\
>\text { Software's and Applications for } \\
\text { Consumers } \\
>\begin{array}{l}\text { Durable \& lightweight vehicle } \\
\text { body design }\end{array}\end{array}$ & $\begin{array}{l}\text { Masters or Bachelors } \\
\text { engineer in Mechanical, } \\
\text { Software, Electronics \& } \\
\text { Electrical sector }\end{array}$ \\
\hline 3 & $\begin{array}{l}\text { EV } \\
\text { Manufacturing }\end{array}$ & $\begin{array}{ll}> & \text { Machines or robots for } \\
& \text { manufacturing plant } \\
> & \text { Quality testing } \\
> & \text { Human resources } \\
> & \text { Plastic molding }\end{array}$ & $\begin{array}{l}\text { Bachelors/ITI/Diploma } \\
\text { degree in Mechanical, } \\
\text { Electronics \& Electrical } \\
\text { sector and MBA in HR }\end{array}$ \\
\hline 4 & Maintenance & $\begin{array}{l}>\text { Battery problems } \\
\text { Motor issues } \\
\text { Digital display or compatibility } \\
\text { issues with app/software }\end{array}$ & $\begin{array}{l}\text { Engineers for testing \& } \\
\text { supervision, Diploma/ITI for } \\
\text { fitting \& repairing }\end{array}$ \\
\hline 5 & $\begin{array}{l}\text { Infrastructure } \\
\text { Development }\end{array}$ & $\begin{array}{l}>\text { Charging station } \\
>\quad \text { High power electric wiring }\end{array}$ & 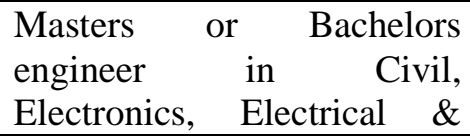 \\
\hline
\end{tabular}




\begin{tabular}{|l|l|l|l|}
\hline & $>\begin{array}{l}\text { Renewable energy generation } \\
\text { (solar, wind, etc) }\end{array}$ & Architect sector \\
\hline
\end{tabular}

\section{TOP COMPANIES IN THE EV INDUSTRY IN INDIA \& COMPETITORS ANALYSIS :}

The automobile industry is working on the 'Make In India' plan by the government of India intending to increase the sale of electric vehicles and to decrease liquid fuel consumption. The companies like Tata, Mahindra, Bajaj, TVS, etc are in the competition to attract customers by giving the best service and offers on electric vehicles. The electric vehicles of top companies in India are compared in the table below. Battery capacity, driving range, Recharge time, Price, and User rating are the parameters considered for comparison. Some of the top-rated electric vehicles and their descriptions are shown in the tables 4 to 6 .

Table 4: Top 5 electric Two-wheelers [22]

\begin{tabular}{|l|l|l|l|l|l|}
\hline Two-wheelers & $\begin{array}{l}\text { Battery } \\
\text { Capacity }\end{array}$ & Driving range & Recharge Time & Price & $\begin{array}{l}\text { User } \\
\text { Rating }\end{array}$ \\
\hline Bajaj Chetak & $2.9 \mathrm{kWh}$ & $95 \mathrm{~km} /$ charge & 5 hours & Rs.1-1.5lakhs & 4.7 \\
\hline Revolt RV400 & $3.2 \mathrm{kWh}$ & $150 \mathrm{~km} /$ charge & 4.5 hours & Rs.1.03-1.18laks & 4.7 \\
\hline Ather 450X & $2.9 \mathrm{kWh}$ & $116 \mathrm{~km} /$ charge & $\begin{array}{l}3 \text { hours 35minutes } \\
(0-80 \%)\end{array}$ & $\begin{array}{l}\text { Rs.1.27- } \\
1.461 \text { lakhss }\end{array}$ & 4.5 \\
\hline TVS iQube Electric & $4.4 \mathrm{kWh}$ & $75 \mathrm{~km} /$ charge & 6 hours & Rs.1lakhs & 4.4 \\
\hline Ultraviolette F77 & $4.2 \mathrm{kWh}$ & $\begin{array}{l}130- \\
150 \mathrm{~km} / \text { charge }\end{array}$ & 1.5 hours & Rs.3laks & 4.4 \\
\hline
\end{tabular}

Table 5: Top 5 electric Three-wheelers [23]

\begin{tabular}{|l|l|l|l|l|l|}
\hline Three-wheelers & $\begin{array}{l}\text { Battery } \\
\text { Capacity }\end{array}$ & Driving range & Recharge Time & Price & $\begin{array}{l}\text { User } \\
\text { Rating }\end{array}$ \\
\hline Mahindra Treo & $5.4 \mathrm{kWh}$ & $130-170 \mathrm{~km}$ & $3 \mathrm{hrs} \mathrm{50} \mathrm{mins}$ & Rs. 2.22 lakhs & 4.9 \\
\hline Bajaj RE EV & $4.3 \mathrm{kWh}$ & $120 \mathrm{~km}$ & 6 hours & Rs. 2lakhs & 4.7 \\
\hline Kinetic Safar & $8.2 \mathrm{kWh}$ & $130 \mathrm{~km}$ & $2-3 \mathrm{hrs}$ & Rs.2.2 lakhs & 4.5 \\
\hline Atul Elite Cargo & $1.2 \mathrm{kWh}$ & $80 \mathrm{~km}$ & $8-10 \mathrm{hrs}$ & Rs.1.04lakhs & 4.0 \\
\hline $\begin{array}{l}\text { Kinetic Safar } \\
\text { Shakti }\end{array}$ & $8.2 \mathrm{kWh}$ & $80 \mathrm{~km}$ & $10-12 \mathrm{hrs}$ & Rs.1.53lakhs & 4.0 \\
\hline
\end{tabular}

Table 6: Top 5 electric Four-wheelers [24, 25, 26]

\begin{tabular}{|l|l|l|l|l|l|}
\hline $\begin{array}{l}\text { Four Wheelers } \\
\text { (Cars) }\end{array}$ & $\begin{array}{l}\text { Battery } \\
\text { Capacity }\end{array}$ & Driving range & Recharge Time & Price & $\begin{array}{l}\text { User } \\
\text { Rating }\end{array}$ \\
\hline Jaguar I-Pace & $90.0 \mathrm{kWh}$ & $\begin{array}{l}470 \mathrm{~km} / \text { full } \\
\text { charge }\end{array}$ & $\begin{array}{l}0-80 \% \text { in } 85 \\
\text { minutes, an }\end{array}$ & $\begin{array}{l}\text { Rs 1.05 crore to } \\
\text { Rs 1.12 crore }\end{array}$ & 4.9 \\
\hline $\begin{array}{l}\text { Mercedes-Benz } \\
\text { EQC }\end{array}$ & $80 \mathrm{kWh}$ & $\begin{array}{l}455 \mathrm{~km} \text { battery } \\
\text { only }\end{array}$ & $\begin{array}{l}42 \mathrm{~h} \text { at 220V, } \\
0.67 \mathrm{~h} \text { at 440V }\end{array}$ & Rs 39.90 Lakh & 4.8 \\
\hline Tata Tigor EV & $21.5 \mathrm{kWh}$ & $\begin{array}{l}142 \mathrm{~km} / \text { full } \\
\text { charge }\end{array}$ & $\begin{array}{l}\text { Normal } \\
\text { charging in 6 } \\
\text { hours and fast } \\
\text { charging will } \\
\text { take 90mins }\end{array}$ & $\begin{array}{l}\text { Starting } \\
\text { Rs.9.54 lakh }\end{array}$ & 4.6 \\
\hline Mahindra e-Verito & $21.2 \mathrm{kWh}$ & $\begin{array}{l}140 \mathrm{~km} \text { full } \\
\text { charge }\end{array}$ & $\begin{array}{l}\text { Fast charging in } \\
1 \text { hour }\end{array}$ & $\begin{array}{l}\text { Starting from } \\
\text { Rs.10 lakhs }\end{array}$ & 4.6 \\
\hline Tata Nexon EV & $30.2 \mathrm{kWh}$ & $\begin{array}{l}312 \mathrm{~km} / \text { full } \\
\text { charge }\end{array}$ & $\begin{array}{l}\text { 0-80\%charge } \\
\text { in 60 } \\
\text { mins }\end{array}$ & $\begin{array}{l}\text { Starting } \\
\text { Rs.13.99 lakh. }\end{array}$ & 4.3 \\
\hline
\end{tabular}




\section{ELECTRIC VEHICLE SALES IN INDIA :}

According to data released by the Society of Manufacturers of Electric Vehicle, two- and three-wheeler sales are down while passenger vehicles post strong growth in the current year. When compared to the previous financial year, the table reveals that EV sales in India were down roughly 20\% [27].

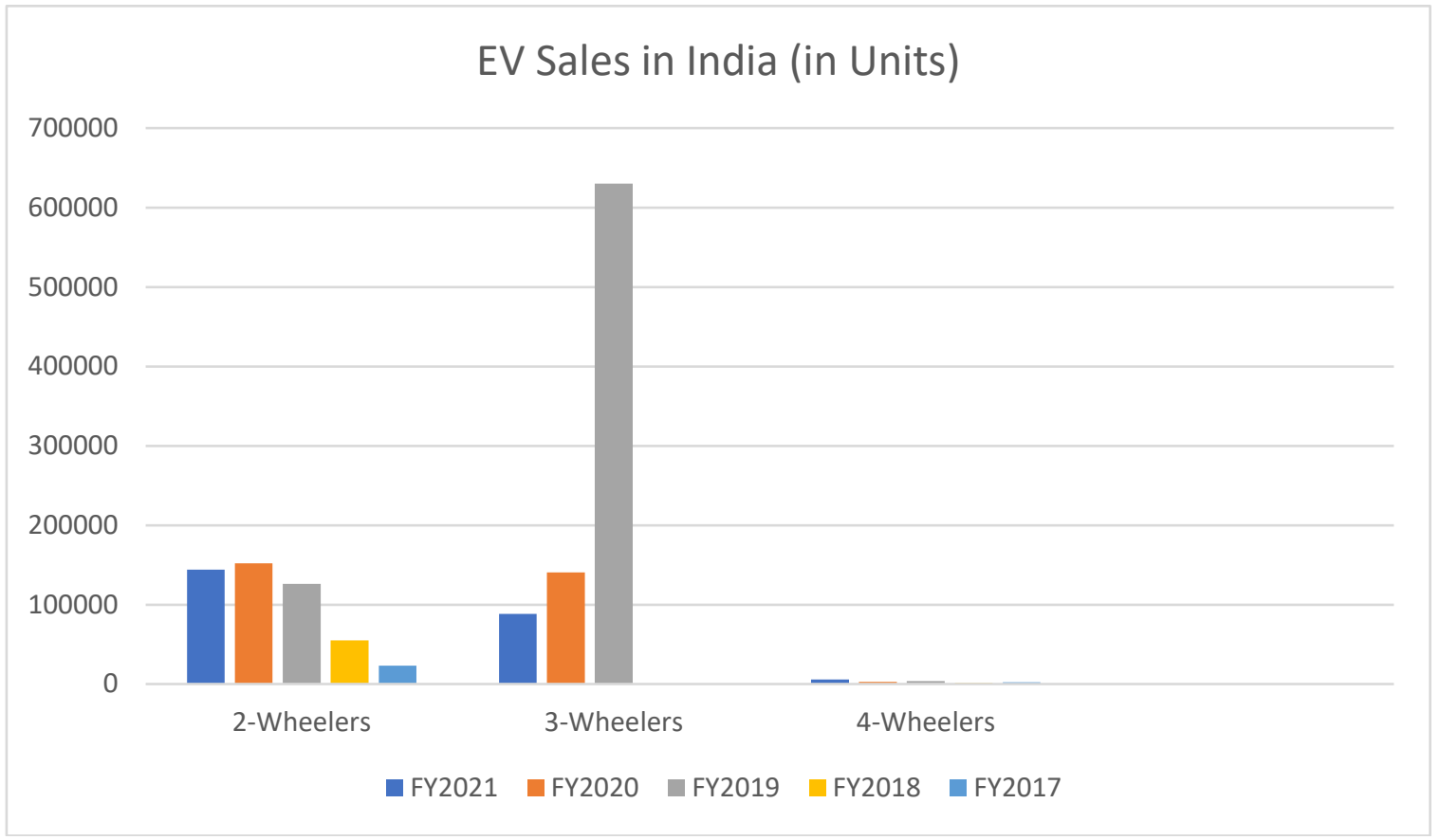

Fig. 1: Electric Vehicle Sales in India [27,28,29].

In FY2020, a total of 2,95,497 electric vehicles were sold but in FY2021 only 2,38,120 electric vehicles were sold. But in FY2019, a maximum sale of 7,59,000 was noticed. According to SMEV, the reason for the decline is not only the charging infrastructure but also due to various reasons like banks refuse to give loans, no clarity about the EV benefits, COVID-19 pandemic, etc [30].

\section{CSR ACTIVITIES :}

Corporate social responsibility is a key element in motivating company sustainability programs. Fleet performs a vital function in projecting suitable company citizenship. Aligning an engaged coverage with the company sustainability method is a requirement. Governmental regulations, worker and customer perceptions of a company's mindset closer to the surroundings are occasionally using fleets to transport faster than the budgets or fleet guidelines which are in place [31].

For companies trying to demonstrate CSR, there's no obtaining removed from the obstacle that's bestowed by a fuel-burning fleet. Switch to an electrical fleet may be a clear positive go the CSR front, which may facilitate strengthening whole values and make competitive advantage in progressively jampacked marketplaces.

Charging stations for electric cars may be considered a CSR activity [32] because of government subsidies for saving the environment. Electric vehicles are100 percent environmentally - friendly.

\section{COVID-19'S EFFECT ON THE ELECTRIC VEHICLE INDUSTRY :}

The COVID19 epidemic has influenced the Indian electric vehicle market, manufacturing units, and travel restrictions across the country. However, in India, the EV sector is still in its infancy. Due to several govt programs and policies, it is predicted to expand at a considerably quicker rate during the forecast period [19]. Electric vehicle production is crucial for achieving long-term targets, though COVID-19 has entered the market, posing threats to the entire sector. The global EV and EV infrastructure market is predicted to grow at a 22.1 percent CAGR between 2020 and 2021, rising from $3.42 \mathrm{~m}$ units in 2020 to $4.18 \mathrm{~m}$ units in 2021 . The 2021 prediction is predicted to be 34 percent lower 
than pre-COVID forecasts.

\section{EV \& EV Infrastructure Market -Pre Vs. Post COVID-19}

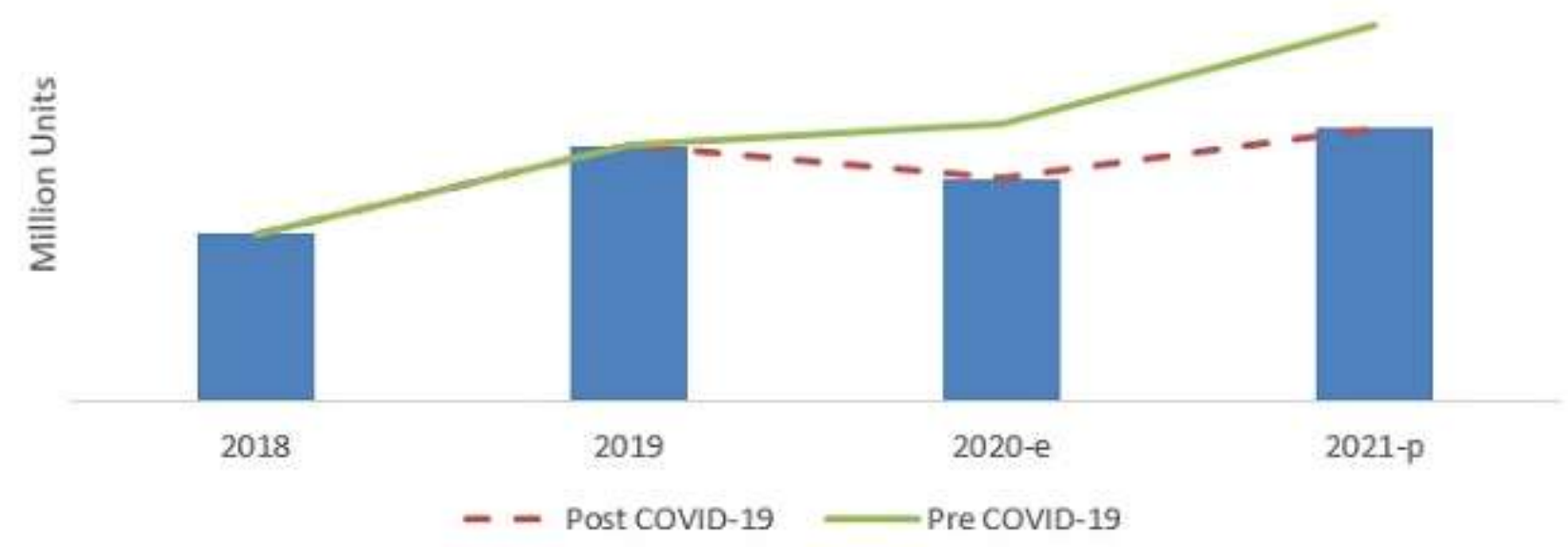

Source: Press Release, Investor Relation Presentation, Annual Report, Expert Interview, and MarketsandMarkets Analysis

Fig. 2: Pre and Post Analysis of COVID19 impact on EV \& EV Infrastructure market [28].

Since the mid-2010s, the worldwide electric vehicle industry has exploded. The adoption of electric cars has increased in recent years (2014-2019) due to a common vision among governments, corporate leaders, and the general public, and by the end of 2019, the worldwide electric car fleet had reached 7.2 million units, up more than a 40\% increase over the previous year. In 2019, 2.1 million electric vehicles were sold around the world. However, the COVID-19 pandemic is expected to reduce worldwide electric vehicle demand by $15 \%$ in 2020 , to 1.8 million cars, compared to deliveries in 2019 , and by $43 \%$ compared to the pre-COVID projection for 2020 [33].

The global economy is now experiencing unparalleled uncertainty as a result of COVID19. To combat the outbreak of the pandemic, preventive steps such as lockdowns and mobility limits have resulted in a dramatic drop in car purchases across all global consumer markets. Electric cars have also been struck hard, but they have fared better so far. In the worst-case scenario, the total value added (GVA) of the electric vehicle sector in 2020 is $14-16$ percent lower (vehicle production).

COVID-19's Short-Term Effect on the Electric Vehicle Industry [34] :

Rather than bringing value to an already stressed market, electric cars are currently capital hogs for original equipment manufacturers (OEMs). In the near term, electric car prices will inevitably decline. The following are some of the reasons that have harmed the industry.

- Preference of customers: Due to their higher-than-average buying cost, customers could face greater difficulties in obtaining credit, which may stymie electric vehicle purchases. However, since electric cars appear to fall into the luxury market category, where capital-constrained consumers are few, this impact could be less serious.

- Policy and regulatory delays: Regulations and policies aiming at lowering greenhouse gas (GHG) emissions may take longer to implement. It is widely assumed that governments in different countries will change their goals during and after the COVID-19 crisis. The emphasis could also shift to more urgent social and economic questions, which may be a setback for electric car incentives and subsidies.

- The price of crude oil: The ripple effects were also evident in oil prices, which fell into negative territory after reaching new lows. Since rising crude prices are a major driver of electric car adoption, this would be a major setback for electric vehicle product producers and marketers, as economies of scale will be heavily stacked against them. 
- Automatic shut-down of the factory: As COVID-19 spreads around the world, automakers around the world have declared temporary plant shutdowns, with all of them lasting longer than their original resumption dates to ensure employee safety. The scenario is becoming more frightening, as a growing number of European companies are halting operations and automakers in the United States are stretching their shutdown times.

COVID-19's Effect on the Electric Vehicle Industry in the Mid- to Long-Term [34]:

On the other hand, there are a host of reasons that say the electric car market's long-term future would be favourable for the next decade and beyond. Electric car manufacturing will continue to provide opportunities for self-reinforcing cost savings. BEVs and PHEVs will be able to compete with vehicles with internal combustion engines in terms of the total cost of ownership due to increased battery output volume and battery technological developments.

Furthermore, there will be widespread interest and a pressing need for public intervention on key issues such as climate change mitigation, improved urban air quality, increased economic growth, and industrial production. These goals necessitate investment in engineering, including advancements in the hybrid car and battery value chains.

\section{SWOC ANALYSIS :}

SWOC Analysis [35] is the most often used tool for auditing and analyzing the overall strategic position and environment of a company. It forms the foundation for assessing internal and external potential, constraints, and dangers [36]. The following SWOC analysis is done for the electric vehicle industry's role towards achieving and realizing 'Make in India' [37-38].

\section{Strengths:}

- Eco-accommodating

- Silent

- Low expense of proprietorship

- Cheaper to run

- Energy-saving

- Simpler component

Weaknesses:

- Charging time

- Lack of re-energizing foundation

- Batteries change is costly

\section{Opportunities:}

- Governments endowment for proprietorship

- No blockage charges

- Lower charges

- Increasing petroleum product cost

\section{Challenges:}

- Purchase cost and resale esteem.

- Additional fleet activity costs related to charging endeavours.

- Energy the board

- Insufficient DC charging framework.

- Rates differ between suppliers.

\section{SUGGESTION BASED ON PREDICTIVE ANALYSIS :}

The growing popularity of electric cars (EVs) is outpacing traditional automakers' sales of internal combustion engines. By 2030, electric vehicles are estimated to account for 51 percent of the market. And today, $60 \%$ of industries are using Artificial Intelligence and data science tools to rate their performance [39]. 
- Maintenance predictive analysis: To achieve high battery performance and operational reliability, it is better to introduce the concept of artificial intelligence, predictive analytics, and data science

- Tech issues for electric vehicles: Because of recent developments in battery and charging technologies, the Electric Vehicle (EV) is now considered the next generation of automobile transportation. However, the physical dimensions, packing environment, and charging of EV batteries remain the primary concern and focus of work in the production of EVs. We have to choose the right battery technology to obtain the proper balance in vehicle design.

- Smart grid technologies and data science: The current market scenario is more impacted by the data science technologies in the space of EV growth. The smart grid is a cost-effective approach to meet the demand for electricity while also cutting carbon emissions. The switch from a powerful fuel or gasoline engine to an electric engine has a big impact on human health and the environment.

- The key to unlocking EV demand is analysis: This is the right time to analyze the EV industry. Using the proper analysis technique, the companies have to come up with ideas to attract customers so that India can move towards green and eco-friendly.

- Awareness among consumers must be increased by manufacturers and the government of India to promote electric vehicles.

- Middle-class customers should be given vehicle loans with a low-interest rate to increase the usage of electric vehicles.

\section{CONCLUSION :}

Electric Vehicles have been evolved in the 21st century. Since its contribution is great towards a better climate, it's one of the important concerns of the world. With the current scenario of environmental pollution, we need electric vehicles to overcome these problems. Most importantly, these electric vehicles produce zero emissions hence there is no risk of air and noise pollution.

The technical design of electric vehicles is simpler and more efficient. As a result, these vehicles are more dependable and easier to maintain. Dissimilar to fuel-controlled vehicles, these EV's have fewer parts, and electricity is stored in their high-end batteries. In the most recent couple of years, the price of oil has been raised harshly, hence EV's are one of the biggest advantages. Directly and indirectly, these electric vehicles are environmentally friendly.

The main disadvantage of the electric vehicle's being it needs 3 to 10 hours of battery recharge. It consumes more electricity to get fully recharged. If environment-friendly resources are used for producing electricity, then it's a boon. But in case if the burning fossil fuels are used to generate electricity, then it creates Little environmental pollution. These days our climate is unpredictable. Electric vehicles are the future of the automobile industry. Since its consumption of oil is less, it's a boon to the weather and climate. The only concern is to find an alternative source to generate environmentally friendly electricity. Time to change ourselves to start using electric cars to reduce the I'll effect to the environment and to gain benefit.

\section{REFERENCES :}

[1] Aithal, P. S. (2017). Industry Analysis-The First Step in Business Management Scholarly Research. International Journal of Case Studies in Business, IT and Education (IJCSBE), 1(1), 1-13.

[2] Introduction to the electric vehicle industry. Retrieved from https://en.wikipedia.org/wiki/Electricvehicle on 15/05/2021.

[3] Sharmila, B, Srinivasan, K., Devasena, D., Suresh, M., Hitesh Panchal, Ashokkumar, R., Meenakumari, Kishor Kumar sadasivuni \& Ronakkumar Rajnikant Shah (2021). Modelling and performance analysis of electric vehicle, International Journal of Ambient Energy, 1(1), 1-8.

[4] Goel, S., Sharma, R. and Rathore, A. K. (2021). A review on barrier and challenges of electric vehicle in India and vehicle to grid optimization, Elsevier Ltd: Transportation Engineering, 4(1), $1-14$. 
[5] Goel, P., Sharma, N., Mathiyazhagan, K., Vimal, K. E. K., (2021). Government is trying but consumers are not buying: A barrier analysis for electric vehicle sales in India, Elsevier Ltd: Sustainable Production and Consumption, 28(1), 71-90.

[6] Samveg Saxena, Anand Gopal, Amol Phadke (2014). Electrical consumption of two-, three- and four-wheel light-duty electric vehicles in India, Elsevier Ltd: Applied Energy, 115(1), 582-590.

[7] Sharma, S., \& Anwer, N. (2021). Electric Vehicles Adoption in India: A Comparative Data Analysis of Different States. In: Sandip A. Kale editor, Advances in Electrical and Electronics Engineering, Pune: Grinrey Publications, 2021, pp. 97-106.

[8] Mirwani, P. M., \& Kavitha, N. L. (2021). Indian Electric Vehicles Market: The Way Ahead. Embracing change \& Transformation, 1(1), 1-8.

[9] Chan, C. C. (1993). An overview of electric vehicle technology. Proceedings of the IEEE, 81(9), 1202-1213.

[10] Xu, K., Ren, S., Xie, B., Dou, X., \& Zhang, P. (2020, September). Optimization Strategy of Electric Vehicle Charging Based on Electricity Price Demand Response. In 2020 12th IEEE PES AsiaPacific Power and Energy Engineering Conference (APPEEC) (1-5). IEEE.

[11] Liu, J., Zou, D., Chen, Y., \& Chu, Z. (2020, September). Analysis of Electric Vehicle Charging Facilities Operation Data. In 2020 IEEE 5th International Conference on Intelligent Transportation Engineering (ICITE) (422-426). IEEE.

[12] Vražić, M., Vuljaj, D., Pavasović, A., \& Pauković, H. (2014, May). Electric vehicle number assessment for year 2020 in Croatia. In 2014 IEEE International Energy Conference (ENERGYCON) (1531-1536). IEEE.

[13] Totev, V., \& Gueorgiev, V. (2020, June). Efficiency of Regenerative Braking in Electric Vehicles. In 2020 21st International Symposium on Electrical Apparatus \& Technologies (SIELA) (1-4). IEEE.

[14] Archana, A. N., \& Rajeev, T. (2020, January). Reliability Index based Approach for Allocating EV Charging Station in a Distribution System. In 2020 IEEE International Conference on Power Electronics, Smart Grid and Renewable Energy (PESGRE2020) (1-6). IEEE.

[15] Das, S. (2019, October). Emerging trends in Electric Vehicle in Indian market. In 2019 3rd International Conference on Recent Developments in Control, Automation \& Power Engineering (RDCAPE) (514-518). IEEE.

[16] Shereef, R. M. (2020, January). Optimal Scheduling of Electric Vehicles for Peak Clipping Services. In 2020 IEEE International Conference on Power Electronics, Smart Grid and Renewable Energy (PESGRE2020) (1-6). IEEE.

[17] Ghatikar, G., Pillai, R. K., \& Ahuja, A. (2016, December). Electric transportation action plan for India. In 2016 First International Conference on Sustainable Green Buildings and Communities $(S G B C)$ (1-6). IEEE.

[18] Sasidharan, C., Chandra, D., \& Das, S. (2019, December). Application of Analytic Hierarchy Process for the Siting of Electric Vehicle Charging Infrastructure in India. In 2019 IEEE Transportation Electrification Conference (ITEC-India) (1-6). IEEE.

[19] Government incentives for plug-in electric vehicles are retrieved from https://www.cardekho.com/indiacarnews/top-evfriendly-states-in-india-that-offer-the-bestincentives-to-electric-car-buyers-27251.htm on 23/06/2021.

[20] EV Market, trends, COVID19 impact, https://www.mordorintelligence.com/industryreports/india-electric- vehicle-market on 23/06/2021.

[21] Job Opportunities in electric vehicle industry in India is retrieved from https://evduniya.com/evindia/job-opportunities-in-electric-vehicle-industry.html on 20/05/2021. 
[22] Top five electric two-wheelers retrieved from https://www.bikedekho.com/bike-collection/5-bestelectric-two-wheelers-in-india.htm on 24/05/2021.

[23] Top five electric three-wheelers retrieved from https://trucks.cardekho.com/en/trucks/ on $26 / 05 / 2021$

[24] Best Electric Cars in India, List of the Top Electric Cars in India. Retrieved from https://www.godigit.com/motor-insurance/car-insurance/find/best-electric-cars-in-india $\quad$ on $30 / 05 / 2021$

[25] Electric Car Zone. Retrieved from https://www.cardekho.com/electric-cars on 30/05/2021.

[26] Best Electric Cars to Buy In India In 2021. Retrieved from https://www.cars24.com/blog/bestelectric-cars-top-4-ev-s-to-buy/ on 30/05/2021.

[27] Electric vehicle sales in India FY2021 and 2020 are retrieved from https://www.autocarindia.com/car-news/smev-cumulative-ev-sales-down-1941-percent-infy2021-420595 on 02/06/2021.

[28] Electric vehicle sales in India FY2019 and 2018 are retrieved from https://www.autocarindia.com/car-news/ev-sales-in-india-cross-75-lakh-mark-in-fy2019-412542 on $02 / 06 / 2021$.

[29] Electric vehicle sales in India FY2017 and 2016 is retrieved from https://www.autocarpro.in/newsnational/ev-sales-in-india-grow-to-56-000-units-in-fy2018--demand-up-for-2ws-but-abysmalfor-pvs-41063 on 02/06/2021

[30] The decline in the sales of electric vehicles is retrieved from https://www.financialexpress.com/auto/electric-vehicles/why-electric-vehicle-sales-in-india-arelow-and-its-not-just-charging-infrastructure-range-finance/2238016/ on 04/06/2021.

[31] Antich, M. (2020). Corporate Social Responsibility Driving EV Adoption. Retrieved from https://www.automotive-fleet.com/348511/justifying-electric-vehicles-through-alongtermacquisition-strategy on 08/06/2021.

[32] CSR activity is retrieved from https://www.livemint.com/ Auto/BzjIje0GCOkHh2y2sdKGEP/Charging-stations-for-electric-cars-may-be-considered-CSRac.html on 08/06/2021.

[33] COVID-19 impact on EV and EV Infrastructure is retrieved from https://www.marketsandmarkets.com/Market-Reports/covid-19-impact-on-electric-vehiclemarket-181970499.html on 10/06/2021.

[34] COVID-19 Impact Analysis on Electric Vehicle Industry is retrieved from https://www.psmarketresearch.com/market-analysis/covid19impact-analysis-electric-vehicleindustry on 10/06/2021.

[35] Aithal, P. S. \& Suresh Kumar, P. M. (2015). Applying SWOC Analysis to an Institution of Higher Education. International Journal of Management, IT and Engineering (IJMIE), 5(7), 231-247.

[36] Aithal, P. S. (2017). Industry Analysis-The First Step in Business Management Scholarly Research. International Journal of Case Studies in Business, IT and Education (IJCSBE), 1(1), 113.

[37] SWOT analysis for electric vehicles is retrieved from

https://www.researchgate.net/figure/ SWOT-analysis-for-electricvehicles_tbl1_260134783. Retrieved on 15/06/2021.

[38] Opportunities \& Challenges in Electric Vehicle Car Sharing. (2016). Retrieved from https://www.slideshare.net/AshleyDuplanty/reachnow-opportunities-challengesinelectricvehicle-car-sharing on 15/06/2021.

[39] Using Data Science to Map the Electric Vehicles (EV's) Data is retrieved from https://soulpageit.com/using-data-science-to-map-the-electricvehicles-evs-data/ 20/06/2021. 